U1) norden

Pohjoismaiden kansainvälinen profilointi- ja asemointistrategia

2015-2018

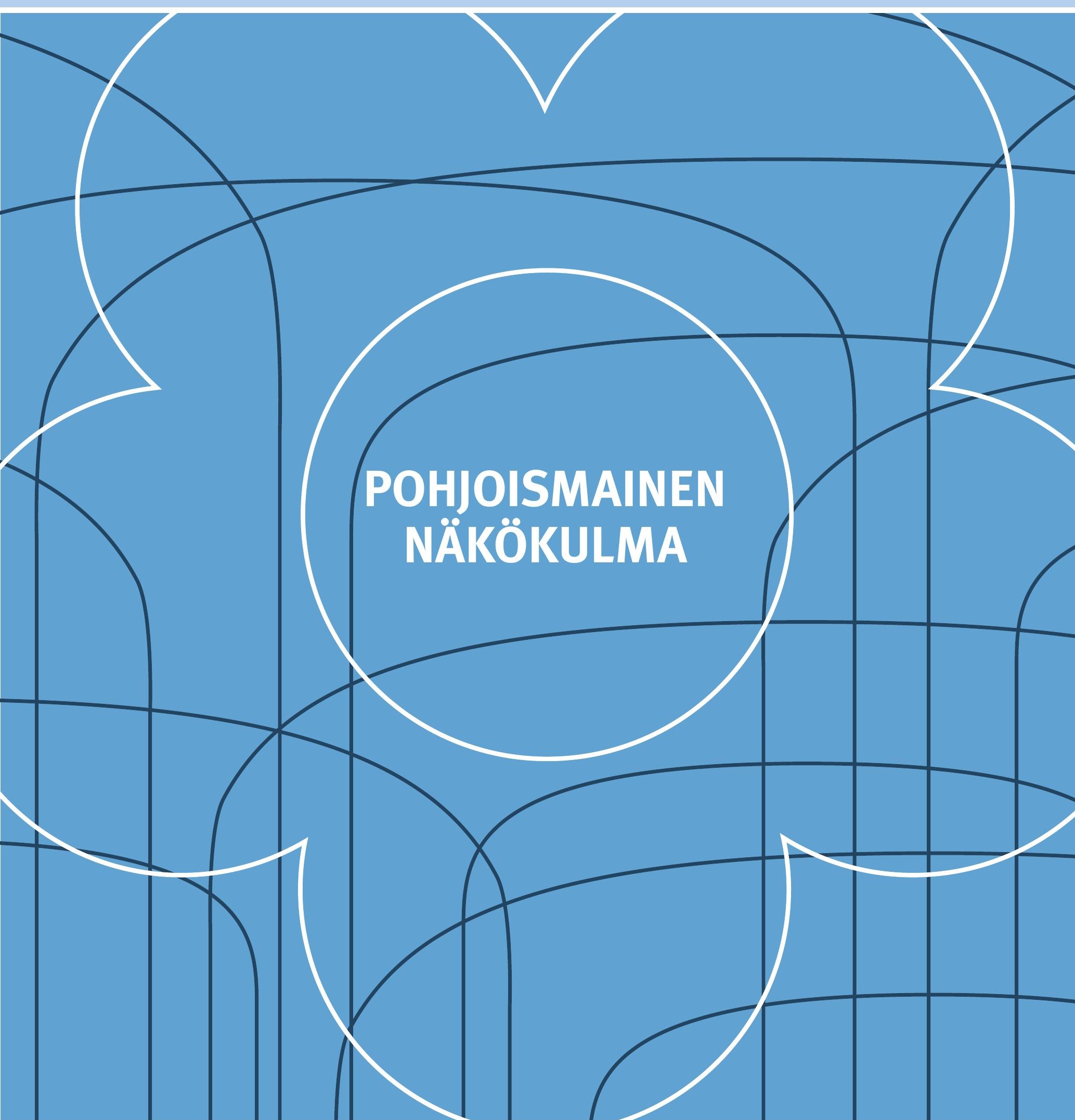




\section{Pohjoismaiden kansainvälinen profilointi- ja asemointistrategia}

2015-2018

ISBN 978-92-893-3928-5 (PRINT)

ISBN 978-92-893-3929-2 (PDF)

http://dx.doi.org/10.6027/ANP2015-706

ANP 2015:706

(c) Pohjoismaiden ministerineuvosto 2015

Ulkoasu: Erling Lynder

Paino: Rosendahls-Schultz Grafisk

Painos: 400

Printed in Denmark

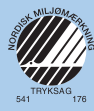

www.norden.org/fi/julkaisut

Pohjoismaiden ministerineuvosto

Ved Stranden 18

DK-1061 København K

Puhelin (+45) 33960200

\section{Pohjoismainen yhteistyö}

Pohjoismainen yhteistyö on yksi maailman laajimpia alueellisia yhteistyömuotoja. Yhteistyön piiriin kuuluvat Islanti, Norja, Ruotsi, Suomi ja Tanska sekä Ahvenanmaa, Färsaaret ja Grönlanti.

Pohjoismaista yhteistyötä tehdään politiikan, talouden ja kulttuurin aloilla tärkeänä osana eurooppalaista ja kansainvälistä yhteistyötä. Pohjoismaisen yhteisön tavoitteena on vahva Pohjola vahvassa Euroopassa.

Pohjoismainen yhteistyö pyrkii vahvistamaan pohjoismaisia ja alueellisia etuja ja arvoja globaalissa maailmassa. Maiden yhteiset arvot lujittavat osaltaan Pohjolan asemaa yhtenä maailman innovatiivisimmista ja kilpailukykyisimmistä alueista. 


\section{Pohjoismaiden kansainvälinen profilointi- ja asemointistrategia}

2015-2018

Esipuhe $\quad 5$

1. Taustaa $\quad 7$

$\begin{array}{ll}1.1 \text { Pääministerit } & 7\end{array}$

$\begin{array}{ll}1.2 \text { Yhteistyöministerien visio } & 7\end{array}$

$\begin{array}{ll}1.3 \text { Nordic Cool } & 7\end{array}$

$\begin{array}{ll}1.4 \text { Esitutkimus } & 8\end{array}$

2. Pohjoismaiden kansainvälinen profilointi-

ja asemointistrategia $\quad 9$

2.1 Strategian tavoite $\quad 9$

$\begin{array}{ll}2.2 \text { Yhteinen alusta } & 10\end{array}$

2.3 Pohjoismainen näkökulma havainnollistettuna 11

3. Tarina pohjolasta 13

4. Strategian käyttö 16

4.1 Strategiset profilointialueet 16

$\begin{array}{ll}\text { 4.2 Priorisoidut maantieteelliset alueet } & 19\end{array}$

5. Kohderyhmät 20

6. Tavoitteet 21

7. Hankkeiden ja toimien menestyksen kriteerit 22

$\begin{array}{ll}\text { 8. Budjetti } 23 & 23\end{array}$

9. Aikataulu ja toteutus 24

9.1 Täytäntöönpanon aikataulu $\quad 24$

10. Käytännön välineet 25 


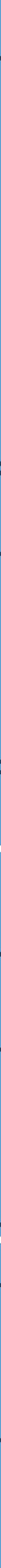




\section{Esipuhe}

Pohjolassa on vetovoimaa. Pohjoismainen ruoka, muotoilu, elokuva, musiikki ja kirjallisuus ovat jo pitkään tehneet Pohjoismaista tunnettuja kansainvälisesti. Menestystarinoita syntyy kaikissa Pohjoismaissa ja usein niihin liittyy pohjoismainen ulottuvuus - pohjoismainen tavaramerkki.

Kansainväliseen tietouteen Pohjola nousi toden teolla kuitenkin vasta talouskriisin jälkimainingeissa. Kriisi osoitti, että pohjoismainen yhteiskunta- ja hyvinvointimalli pystyi taas kerran uudistumaan, mikä antoi muille valtioille aihetta pohtia, voisiko pohjoismainen malli toimia mahdollisena puskurina ja vakiinnuttavana tekijänä yhä epävakaammaksi muuttuvassa maailmantaloudessa.

Kuitenkin myös meillä Pohjoismaissa on edessämme monia vaativia haasteita. Emme suinkaan ole täydellisiä ja ehkäpä juuri se tekee meistä kiinnostavia muille.

Samaan aikaan Pohjoismaat ovat kuitenkin avoimuutta, luottamusta, tasa-arvoa, ympäristöä ja onnellisuutta mittaavien kansainvälisten tutkimusten kärjessä. Nämä arvot haluamme jakaa myös muun maailman kanssa, kuten myös käytännönläheisen politiikkamme, synkät dekkarimme ja vahvan naiskuvamme.

Tämän vuoksi Pohjoismaiden pääministerit ovat useissa yhteyksissä toivoneet, että Pohjoismaiden kansainvälinen näkyvyys kasvaisi. Pohjoismaissa on tehty maiden omaa kansainvälistä profilointityötä onnistuneesti jo vuosia. Pohjoismaita halutaan nyt kuitenkin profiloida yhteisesti pohjautuen pääministerien ajatukseen siitä, että yhdessä olemme vahvempia.

Yhdessä toimimalla saamme enemmän poliittista ja taloudellista vaikutusvaltaa ja myös paremmat vaikutusmahdollisuudet maailmanlaajuiseen kehitykseen. Lisäksi voimme kehittyä myös itse kohtaamalla muita.

Tavoitteena ei ole luoda Pohjolasta homogeenistä kuvaa ja antaa vaikutelmaa, että kaikki Pohjoismaiden asukkaat, organisaatiot ja hallitukset ajattelevat ja toimivat samoin. Emme myöskään halua korostaa maiden omia erityispiirteitä, vaan rakentaa yhteiselle pohjalle, joka koostuu pohjoismaisesta näkökulmasta, arvoista ja yhteiseen historiaan perustuvasta kulttuurista. 
Uusi profilointi- ja asemointistrategia merkitsee alkua uudelle historialliselle yhteistyölle Pohjoismaiden välillä pohjoismaista näkyvyyttä systematisoimalla ja lisäämällä.

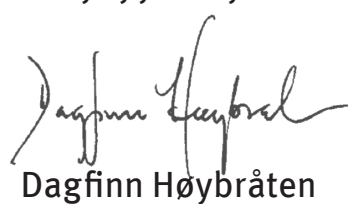

Pohjoismaiden

ministerineuvoston pääsihteeri
Fyygi: $\tan m$

Islannin pohjoismainen

yhteistyöministeri 


\section{Taustaa}

Pohjoismaiden ministerineuvoston sihteeristö on laatinut pohjoismaisten yhteistyöministerien toimeksiannosta Pohjoismaiden kansainvälisen profilointi- ja asemointistrategian. Työ on kytketty laajalti ympäröivään maailmaan, Pohjoismaiden julkisiin ja yksityisiin sektoreihin sekä pohjoismaisen yhteistyön sisäisiin verkostoihin. Jatkossa sihteeristö hallinnoi ja koordinoi strategiaan liittyvää työtä yhteistyössä ja vuorovaikutuksessa maiden kanssa.

Strategia sisältää strategisia suuntaviivoja sille, miten Pohjoismaita ja niiden sidosryhmiä tulisi profiloida kansainvälisesti, ja sitä voidaan tarjota myös virallisen pohjoismaisen yhteistyön ulkopuolisille toimijoille.

\subsection{Pääministerit}

Pääministerit toivat Mývatnilla 27. toukokuuta 2014 järjestetyssä kokouksessaan ilmi vahvan toiveen pohjoismaisen koordinoinnin ja näkyvyyden lisäämisestä ja asettivat etusijalle muun muassa alueellisen brändäystyön tavoitteena vahvistaa Pohjoismaiden kilpailukykyä ja lisätä maiden kansainvälisiä vaikutusmahdollisuuksia.

\subsection{Yhteistyöministerien visio}

Pohjoismaisten yhteistyöministerien visiojulistus pohjoismaiselle yhteistyölle Yhdessä olemme vahvempia ${ }^{1}$ nostaa Pohjolan innovatiivisuuden, näkyvyyden ja ulospäin suuntautuneisuuden tärkeiksi yhteistyötä luonnehtiviksi piirteiksi ja korostaa, miten yhteispohjoismaiset kokemukset voivat merkitä muille paljon maailmassa, jossa alueellisen yhteistyön merkitys kasvaa. Visio perustuu neljään pilariin:

- Rajaton Pohjola

- Innovatiivinen Pohjola

- Näkyvä Pohjola

- Ulospäin suuntautunut Pohjola

\subsection{Nordic Cool}

Vuonna 2013 Washington D.C.:ssa Yhdysvalloissa menestystä niittäneen Nordic Cool -kulttuurifestivaalin seurauksena heräsi kiinnostus toteuttaa lisää profilointitoimia, joihin osallistuisi useita toimijoita kaikkialta Pohjoismaista. Yhtäaikaisesti Kennedy Centerin profiloivien kulttuuritapahtumien kanssa järjestettiin paljon muuta toimintaa tavoitteena viestiä Pohjoismaiden annista myös innovoinnin ja politiikan aloilla. Onnistuneen medianäkyvyyden myötä tapahtuman kerrannaisvaikutukset ulottuivat laajalle. Lisäksi opittiin, että suurten, yhteisten

1 Pohjola-yhdessä olemme vahvempia Pohjoismaiden yhteistyöministerien visio pohjoismaiselle yhteistyölle (2014). 
panostusten toteuttaminen vaatii aikaa ja resursseja ${ }^{2}$ ja että strateginen ajattelu on ratkaisevaa.

\subsection{Esitutkimus}

Talven 2013-2014 aikana toteutettiin kattava esitutkimus, jossa Pohjoismaita kehotetaan yhteistyöministerien vision tapaan perustamaan profilointitiimi, johon kuuluu sekä julkisen että yksityisen sektorin pohjoismaisia ja kansainvälisiä edustajia. Esitutkimuksesta ilmeni, että strategian laatimiselle on laaja tuki. ${ }^{3}$ Strategialla voidaan

- taata Pohjoismaiden profiloinnin yhtenäisyys

- nostaa esiin ja selventää yhteisiä viestejä.

Alla on esitutkimuksessa ja sitä seuranneessa työssä ilmenneitä perusteluja sille, miksi strategia tulee laatia ja miksi juuri nyt:

- Maailmalla Pohjoismaat määritellään yhdeksi kokonaisuudeksi - etenkin maantieteellisen etäisyyden kasvaessa.

- Maailmalla on alettu kiinnittää entistä enemmän huomiota Pohjoismaihin ja pohjoismaiseen malliin. Alueen mainetta on nostanut vuonna 2008 alkaneen talouskriisin selättäminen sekä muut ratkaisut hyvinvointikysymyksiin, mutta myös menestys kulttuurin, luovuuden ja innovaatioiden saralla.

- Sekä julkiset että yksityiset sektorit ovat hyvin kiinnostuneita Pohjoismaiden yhteisestä profiloinnista lisäarvon luomiseksi.

- Pohjoismaat ovat kaiken kaikkiaan kansainvälisten mittareiden kärjessä avoimuuden, suvaitsevaisuuden ja luottamuksen osalta. Kansainväliset mediat ottavat tämän esiin periaatteessa aina Pohjoismaista puhuttaessa.

- Pohjoismaisen tavaramerkin vahvuuden vaalimiseksi, viestin edelleen viemiseksi ja toivotun vaikutuksen aikaan saamiseksi meidän on otettava tavaramerkki haltuun, tehtävä aktiivisesti työtä sen parissa ja viestittävä siitä yhtenäisesti ja selkeästi.

2 Utvärdering av kommunikationseffekter Nordic Cool 2013, Gullers Grupp (2013). 


\section{Pohjoismaiden kansainvälinen profilointi- ja asemointistrategia}

Muualla maailmassa Pohjoismaat mielletään pääosin yhdeksi kokonaisuudeksi. ${ }^{4}$ Kuva on myönteinen paljolti sen vuoksi, että Pohjoismaissa on onnistuttu löytämään ratkaisuja taloudellisiin ja poliittisiin haasteisiin, joiden parissa painitaan sekä meillä että muualla. Pohjoismaisesta mallista on tullut käsite. Jokainen Pohjoismaa on rakentanut oman mallinsa rinnakkain Pohjoismaiden välillä tehdyn laajan ja pysyvän yhteistyön kanssa.

Pohjoismaiden kehityksen myönteinen jatkuminen riippuu meitä ympäröivän maailman tapahtumista ja siitä, että muut ovat kiinnostuneita meistä. On oma etumme olla mukana edistämässä sekä omaa että muiden tulevaisuutta vaihtamalla ajatuksia, osaamista, kokemuksia, palveluita ja tavaroita.

Kilpailu paikasta kansainvälisellä areenalla on kovaa, ja Pohjoismaiden kaltaiset pienet maat voivat parantaa näkyvyyttään ja vaikutusvaltaansa toimimalla yhdessä. Yhteisenä aloitteena toteutettavien koordinoitujen profilointitoimien avulla voidaan saada aikaan synergiaa maiden julkisilla ja yksityisillä sektoreilla.

Pohjoismaiden profilointi- ja asemointistrategia sisältää strategisia suuntaviivoja sille, miten Pohjoismaita ja sen sidosryhmiä profiloidaan kansainvälisesti. Strategia on ensimmäinen vaihe kauaskantoisessa panostuksessa systematisoida ja varmistaa Pohjoismaiden johdonmukainen profilointi. Se on myös tarjolla muille antaen tukea koordinoidulle yhteistyölle silloin, kun siitä saadaan lisäarvoa kyseisille toimijoille. Profiloinnin ja asemoinnin lisäksi on myös muita syitä toimia kansainvälisesti, kuten diplomaattisuhteet tai kokemustenvaihto. Tämä strategia ei koske näitä toimia.

Strategia on voimassa 2015-2018, minkä jälkeen sitä arvioidaan perusteellisesti, ja muutosehdotukset esitetään pohjoismaisten yhteistyöministerien (MR-SAM) päätettäväksi. Mahdollisia pieniä päivityksiä tehdään kerran vuodessa ja niistä päättää pohjoismainen yhteistyökomitea (NSK).

\subsection{Strategian tavoite}

Pohjoismaita ja Pohjoismaiden kilpailukykyä ja kansainvälistä vaikutusvaltaa vahvistetaan yhteisenä aloitteena toteutettavilla koordinoiduilla profilointitoimilla.

Pohjoismaiden saamaa myönteistä kansainvälistä huomiota on hyödynnettävä ja vahvistettava entisestään Pohjola-käsitteen paremmalla käytöllä, etenkin niillä markkinoilla, joilla Pohjoismaat tunnetaan paremmin alueena kuin yksittäisinä maina. Useammat 
5 The Global Competitiveness Report 2014-2015, World Economic Forum (2014).

6 Quality of Life Index, The Economist Intelligence Unit (2014).

7 The Global Gender Gap Report 2013, World Economic Forum (2013).

8 En förstudie kring behovet av en gemensam nordisk varumärkesstrategi, Pohjoismaiden ministerineuvoston viestintäosasto ja Happy Forsman \& Bodenfors (2014). koordinoidut toimet vahvistavat myös jo olemassa olevia suhteita maantieteellisillä lähialueilla. Strategian tavoitteena on yksinkertaistaa ja parantaa Pohjoismaiden kansainvälisen profiloinnin ja asemoinnin parissa tehtävää työtä. Strategia selittää profiloinnin tarkoituksen, antaa tukea ja ohjaa eteenpäin kaikkien osapuolten käyttöön tarkoitettuihin konkreettisiin välineisiin.

\subsection{Yhteinen alusta}

Pohjoismaiden yhteisen aloitteen avulla jokainen yksittäinen Pohjoismaa tai toimija voi tuoda esiin asioita, joita ei voi sanoa yksinomaan ruotsalaisena, tanskalaisena, norjalaisena, suomalaisena, islantilaisena, ahvenanmaalaisena, färsaarelaisena tai grönlantilaisena. Toimijat voivat esimerkiksi profiloida itseään osana vahvaa 26 miljoonan asukkaan aluetta, jonka elinkeino- ja kulttuuritarjonta on suurta ja monipuolista, puhumattakaan vaihtelevasta ja kiehtovasta luonnosta.

Juuri tässä yhteydessä Pohjoismaita voidaan kuvailla tavaramerkkinä eli kuvana, joka vastaanottajan mielessä koostuu mielleyhtymistä, tunteista, kokemuksista ja odotuksista. Kukaan, myöskään yksittäinen maa tai alue, ei voi hallita omaa imagoaan - etenkään nykyajan läpinäkyvässä, alati muuttuvassa ja entistä vahvemmin digitalisoituvassa viestintäympäristössä. Imago on ansaittava. Kauaskantoisten ja kestävien suhteiden luomiseksi muihin maihin tarjouksen on oltava aito. On oltava sitä, mitä väittää olevansa ja mitä haluaa olla.

Nimenomaan Pohjoismaita yhteen sitovat tekijät luovat vahvuuden kiinnostuksen herättämiseksi muualla maailmassa. Vuosien tiiviin ja menestyksekkään yhteistyön seurauksena saattaa olla, että Pohjoismaissa pidetään omia yhteisiä vahvuuksia itsestäänselvyyksinä. Kuitenkin on tärkeää muotoilla viestintäämme ja pyrkimyksiämme ohjaavassa Pohjoismaiden profilointi- ja asemointistrategiassa ne yhteiset vahvuudet, joita katsomme omaavamme suhteessa muuhun maailmaan.

Mistä johtuu, että Pohjoismaat sijoittuvat niin korkeille sijoille kansainvälisissä kilpailukyvyn, ${ }^{5}$ elämänlaadun ${ }^{6}$ ja tasa-arvon ${ }^{7}$ mittauksissa? Entä mistä johtuu, että pohjoismaisesta luovuudesta ja kulttuurista ollaan niin kiinnostuneita juuri nyt? Maailmalla ollaan uteliaita Pohjoismaiden suhteen sen osalta, miten olemme onnistuneet saamaan aikaan kehitystä ja hyviä tuloksia myös huonoina aikoina. ${ }^{8}$ Mitkä ovat menestyksemme taustatekijät? Miten me sen teemme?

Seuraavan sivun havainnollistavaan kaavioon on koottu tekijöitä, joita tämän strategian laajan kytkentäprosessin aikana on noussut esiin. Kaaviota voidaan ajatella myös tarkastuslistana niistä näkökulmista, joita haluamme edistää viestinnässämme ja suhteissamme muuhun maailmaan. Yksittäin ne eivät ole ainutlaatuisia tai mullistavia, mutta yhdessä niistä muodostuu pohjoismainen ajattelutapa. Kutsumme sitä pohjoismaiseksi näkökulmaksi. 


\subsection{Pohjoismainen näkökulma havainnollistettuna}

\section{TAUSTATEKIJÄT}

\section{MAANTIEDE}

- Suuria pinta-aloja

- Harvaan asuttua

- Metsiä, vuoristoa, peltoja

- Meri ympärillä

- Vaativa ilmasto

- Pimeät talvet

- Kirkas valo kesällä

\section{YHTEISKUNTA}

- Vankka sosiaalinen turvaverkosto ja hyvinvointipalvelut

- Ilmainen koulutus kaikille kansalaisille

- Korkea ja tasainen elintaso

- Tasa-arvoinen työllisyysaste

- Vahva kansalaisyhteiskunta

- Elinkeinoelämä teknisesti korkeatasoista ja erikoistunutta

- Valtio kohdistaa paljon resursseja tutkimukseen ja kehitykseen

\section{HISTORIA}

- Pitkä rauhan jakso Pohjolassa (200 vuotta)

- Kansanliikeperinne

- Pohjoismaisen yhteistyön pitkä perinne:

- Työmarkkinat

- Passiunioni

- Koordinoidut sosiaaliturvaratkaisut

- Pienet yhteiskunnat ovat mahdollistaneet matalan hierarkian

- Pitkät perinteet teollisuuden, innovoinnin ja yrittäjyyden alalla

\section{KULTTUURI}

- Luonnolla on suuri rooli:

- kirjallisuudessa

- taiteessa

- arkkitehtuurissa

- Pohjoismainen luovuus on esillä:

- Nordic Noir

- Nordic Cuisine

- Nordic Design 


\section{Vahvuudet, joita haluamme tuoda esiin}

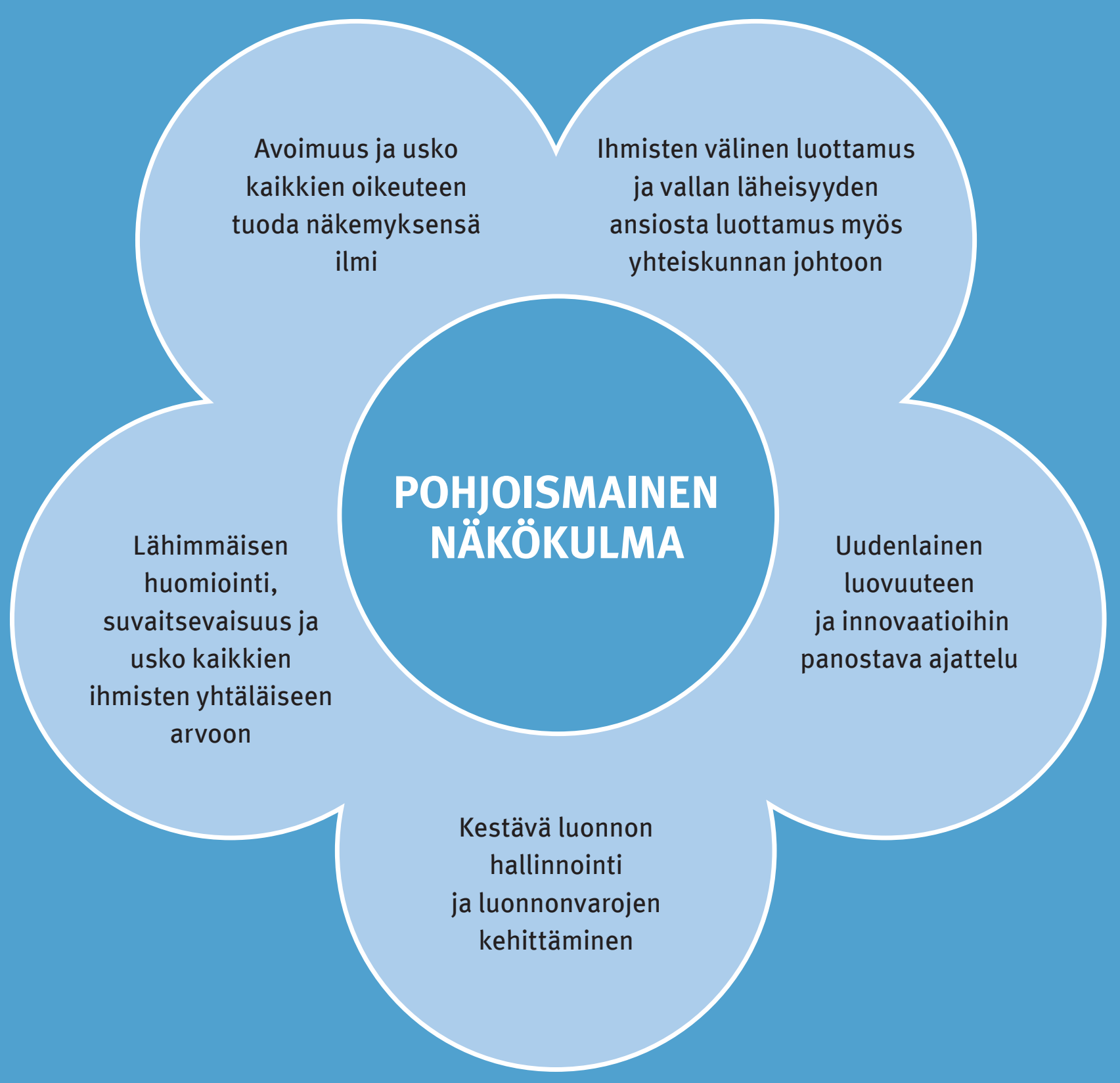




\section{Tarina Pohjolasta}

Pohjoismaisen näkökulman kaavio, joka kuvaa Pohjoismaiden yhteisiä vahvuuksia tunnusmerkkien ja arvojen muodossa, voidaan esittää myös kertomuksena. Tällainen kertomus voi inspiroida Pohjoismaiden edustajia ja puolestapuhujia heidän viestiessään siitä, mitä Pohjoismaat edustavat, mitä maat haluavat ja voivat tehdä suhteessa ympäröivään maailmaan. Tätä lyhyttä ja sen vuoksi yksinkertaistettua kertomusta voidaan kehittää edelleen ja siihen voidaan yhdistää omia viestejä.

\section{Pohjoismainen näkökulma}

Pohjoisen pallonpuoliskon pohjoisosissa asuu suhteellisen pieni ryhmä ihmisiä laajoilla alueilla, joita yhdistävät valtavat merialueet. Näin voidaan kuvata Pohjoismaita eli Islantia, Norjaa, Suomea, Ruotsia ja Tanskaa sekä Ahvenanmaata, Färsaaria ja Grönlantia, joilla on yhteinen 26 miljoonan ihmisen väestö. Kokonaiskuvan ymmärtämiseksi on kuitenkin lisättävä, että maat ovat yhdessä kehittyneet hyvinvointiyhteiskunniksi, jotka sijoittuvat maailman talouksien kärkijoukkoon.

Ankara ilmasto pitkine, pimeine talvineen mutta myös valoisat kesät sekä merien, metsien, vuorten ja peltojen rikkaus ovat saaneet aikaan pohjoismaalaisten erityisen suhteen luontoon. Tarve päästä hengähtämään merelle, vuorille tai metsään on vaikuttanut ympäristöä ja luonnonvaroja suojelevaan ajatteluumme.

Nyky-Pohjolassa haetaan kestäviä ympäristöteknisiä ratkaisuja ja kestävyysajattelu vaikuttaa myös siihen, miten suhtaudumme terveyteen ja ruokaan. Pohjoismaihin työskentelemään, tutkimaan tai kouluttautumaan saapuvat huomaavat pian, miten paljon elinkeinoelämä ja koko yhteiskunta arvostaa mahdollisuutta inhimilliseen ja tasapainoiseen elämään, jossa on tilaa sekä uralle että sosiaalisille suhteille. Toivomme, että Pohjoismaihin saapuvat matkailijat toimivat mielellään pohjoismaisen luonnon ja kulttuurin lähettiläinä.

Suhde luontoon, pohjoisen avaruuden ehtoihin, on paljon esillä myös kirjallisuudessa, musiikissa, taiteessa, muotoilussa ja arkkitehtuurissa. Etenkin taide ja luovuus nostavat juuri nyt Pohjoismai- 
9 Behöver den nordiska modellen förändras?

Elinkeinoelämän tutkimuslaitos ETLA

\& Pohjoismaiden

ministerineuvosto (2014).

10 The Nordic Way, World Economic Forum, Svenska Institutet (2012).

11 The Nordic Countries The next super model, the Economist (2013).

12 Behöver den nordiska modellen förändras?

Elinkeinoelämän tutkimuslaitos ETLA \& Pohjoismaiden ministerineuvosto (2014). ta maailmankartalle - tämä koskee sekä perinteistä pohjoismaista ilmaisua että kohtaamisia uuden, modernin ja monikulttuurisemman Pohjolan kanssa. Kysyntä Nordic Noir -nimelläkin kulkevalle kirjallisuuden ja elokuvan tyylilajille ei ole koskaan ollut suurempi.

Yhteinen historiamme ei suinkaan ole veretön, mutta maidemme välillä on kuitenkin vallinnut rauha jo yli 200 vuotta. Antelias ja vastaanottava asenne sekä käytännön ratkaisujen löytäminen kaikkien osapuolten eduksi on tunnusmerkkimme ja olemme ylpeitä siitä, että vaikutusvaltaiset pohjoismaalaiset ovat saaneet olla mukana edistämässä viimeaikaisia rauhanneuvotteluita sotivien osapuolten välille. Pohjoismaat haluavat olla läsnä ja aktiivisia rauhaa ylläpitävissä järjestöissä; uskomme, että solidaarinen apu heikossa asemassa oleville tekee maailmasta paremman. Lisäksi Norjassa jaetaan Alfred Nobelin muistoa kunnioittava rauhanpalkinto vuosittain.

Kyky uudistua jatkuvasti nykyhaasteiden vaatimalla tavalla on yksi pohjoismaisen mallin ominaisuuksista. Kansan keskuudessa tapahtuneet muutokset, kuten uskonpuhdistus ja kansanliikkeet työväenliike mukaan lukien, raivasivat historiallisesti tietä, mutta kaikki ottivat mallin nopeasti omakseen. Pohjoismaista mallia luonnehtii nykypäivänä julkinen sektori, joka tarjoaa kansalaisilleen hyvinvointipalveluja ja sosiaalisen turvaverkon. Työmarkkinoita säädellään suurelta osin työmarkkinaosapuolten välisillä työehtosopimuksilla. Yhdessä terveen valtiontalouden kanssa malli on luonut mahdollisuuden tasaisesti jakautuvaan korkeaan elintasoon, korkeaan ja tasa-arvoiseen työllisyysasteeseen sekä mittaviin koulutus- ja tutkimuspanostuksiin. Tavoitteena on hyvä ja kehityskelpoinen elämä sekä yksilön että yhteiskunnan kannalta..,10

Emme tietenkään ole ainoita, jotka pyrkivät löytämään uusia hyvinvointiratkaisuja, mutta pohjoismainen malli otetaan kuitenkin usein esimerkiksi muille eräänlaisena "supermallina". ${ }^{11}$ Huomiota herättää esimerkiksi se, miten naisten korkea työllisyysaste edistää osaltaan sekä tasa-arvoa että korkeaa elintasoa. Sanotaan, että sosiaalisen turvaverkon antama turvallisuus on vaikuttanut myös Pohjoismaiden innovointikykyyn. Ihmiset voivat ja uskaltavat ajatella uudella tavalla, koska koko olemassaolo ei ole uhattuna. Maksuton koulutus on korkean ja laajan osaamistason perusta. Koska tutkimuspanostuksemme ovat maailman mittakaavassa huomattavia, meillä on täällä pohjoisessa korkean teknologian moderneja yhteiskuntia. $^{12}$

Kaikki lähti siitä, että aktiiviset ihmiset perustivat yhdistyksiä ja kehittivät demokratiaa. Pohjoismaiden pienissä ja yhdistyselämään panostavissa yhteiskunnissa hierarkiat pysyivät matalina ja hyvinvointiyhteiskunnan yhteisessä rakennustyössä oli helppo vaatia 
avoimuutta, läpinäkyvyyttä ja vapautta ilmaista mielipiteitä sekä sanallisesti että kirjallisesti. Vähäinen korruptio perustuu läpinäkyvyyteen. Avoimuuden seurauksena luotamme muihin ihmisiin, poliitikkoihin ja oikeusjärjestelmään - tällainen luottamus on ainutlaatuista maailmassa. ${ }^{13}$

Vaikka jokainen Pohjoismaa on valinnut oman tiensä - esimerkiksi kolme Pohjoismaata ovat EU-jäseniä ja kolme Naton jäseniä - maiden tahto tehdä yhteistyötä on kuitenkin suuri. Kansanliike oli tässäkin kehityksen kärjessä viime vuosisadan alussa perustaessaan Pohjola-yhdistyksiä. Kahden maailmansodan jälkeen läheisyyden ja riippuvuuden tunne vahvistui ja näin käynnistyi virallinen yhteistyö sekä hallitusten että parlamentaarikoiden välillä. Nopeasti - paljon ennen Euroopan laajuista yhteistyötä - sen avulla saatiin aikaiseksi Pohjoismaiden passiunioni, yhteiset työmarkkinat sekä koordinoituja sosiaaliturvaratkaisuja.

Hyvinvointia ei ole rakennettu pelkästään yhteistyössä vaan myös yhteisesti. Miten kaltaisemme pienet maat voisivat selvitä muuten? Olemme riippuvaisia toistemme osaamisesta, tuotteista ja ystävyydestä aina ja ikuisesti.

Meillä on pitkä kokemus yhteistyöstä, jonka tavoitteena ovat paremmat ehdot ja yhteiskuntamalli, joka tarjoaa ihmisille arvokkaan ja merkityksellisen elämän kehitysmahdollisuuksineen ja uskomme, että meillä on annettavaa myös niille, jotka etsivät vastauksia tulevaisuuden haasteisiin. Tämä koskee niin ideoita, osaamista, kokemustenvaihtoa kuin innovatiivisia ja kestäviä ratkaisujakin.

Meidän on todettu päässeen pitkälle olemalla pohjoismaisia ja näin ollen meidän tulee myös jatkaa olemalla pohjoismaisia.

Paikkamme maailmassa ja historiamme ovat tietenkin antaneet meille oman ja aivan erityisen näkökulman. Teemme kenties samoja asioita kuin monet muutkin, mutta teemme ne omalla tavallamme yhteiseltä, nimenomaan meidän vahvuutemme määrittelemältä pohjalta, johon sisältyvät:

- avoimuus ja usko kaikkien oikeuteen tuoda näkemyksensä ilmi

- ihmisten välinen luottamus ja vallan läheisyyden ansiosta luottamus myös yhteiskunnan johtoon

- lähimmäisen huomiointi, suvaitsevaisuus ja usko kaikkien ihmisten yhtäläiseen arvoon

- kestävä luonnon hallinnointi ja luonnonvarojen kehittäminen

- uudenlainen luovuuteen ja innovaatioihin panostava ajattelu. 


\section{Strategian käyttö}

Nyt kun Pohjoismaiden kansainvälisen profiloinnin tavoite on kuvailtu, ja yhteiset arvot joista haluamme viestiä tunnistettu, tulee priorisoida mitä viestitään ja missä. Priorisoinnin tarkoitus ei ole estää muita toimia, mutta koordinoidut viestit ovat vahvempia, mikä on edellytys mahdollisuuksillemme vahvistaa asemaamme nykyajan viestiyhteiskunnassa.

Alla esitellään nykyiset priorisoinnit, jotka laaja joukko julkisia ja yksityisiä toimijoita on valinnut profilointialueiksi.

\subsection{Strategiset profilointialueet}

Strategiset profilointialueet tämän strategian aikaperspektiivin puitteissa on laadittu pohjoismaisen yhteistyön yleisten poliittisten priorisointien pohjalta. Niitä ovat tällä hetkellä kestävä pohjoismainen hyvinvointi ja vihreä kasvu sekä maiden omat poliittiset priorisoinnit. Lisäksi valintaan vaikuttavat myös aloitteet kulttuurialan suurpanostuksiksi. Priorisointien tavoitteena on tuoda esiin alueita, joita voidaan kehittää pohjoismaisesta näkökulmasta vuoropuhelussa ympäröivän maailman kanssa, ja niillä on kaksi pääasiallista lähtökohtaa:

1 mitä Pohjola voi tarjota muulle maailmalle

2 miten suhteet ympäröivään maailmaan voivat olla hyödyksi

Pohjoismaille.

Osa toimista voi koskea yhtä tai mahdollisesti useita valittuja profilointialueita, osa voi koskea kaikkia.

\subsubsection{Pohjoismainen malli}

Vuoden 2008 talouskriisin jälkeen kiinnostus niin kutsuttua pohjoismaista mallia kohtaan on kasvanut huomattavasti. Pohjoismainen malli tarkoittaa tiivistetysti, että terveen valtiontalouden avulla luodaan mahdollisuudet tasaisesti jakautuvaan korkeaan elintasoon sekä hyvinvointiin ja sosiaaliturvaan ja että työmarkkinoita säädellään hyvin pitkälle työmarkkinaosapuolten välisin työehtosopimuksin sekä panostetaan laajasti koulutukseen ja tutkimukseen.

Pohjoismainen malli osoittaa, että tasa-arvo johtaa korkeaan työllisyysasteeseen sekä työelämän malliin, joka tarjoaa hyvän elämän myös työn ulkopuolella. Lisäksi avoin ja luottamukseen perustuva yhteiskunta edistää innovatiivista ja luovaa ajattelua. Pohjoismaisen mallin vahvuus piilee sen hyväksi todetussa kyvyssä uudistua ennakoivasti nykyajan haasteisiin vastaamiseksi. Pragmatismissa.

Malli rakentuu myös aktiiviselle suhtautumiselle ympäröivään maailmaan 
ja käsitykselle siitä, että vakaus hyödyttää kauppaa, luo lisää osaamista, molemminpuolista kulttuurista ymmärtämystä sekä kestävää kehitystä. ${ }^{14,15}$

Pohjoismaista mallia kehitetään sopusoinnussa muun maailman kanssa ja uskomme, että se voi kansainvälisesti tarjota ratkaisuja tulevaisuuden haasteisiin. Tämän vuoksi haluamme profiloida sekä pohjoismaisen mallin eri osia että kokonaisuutta.

\subsubsection{Pohjoismaat tietoyhteiskuntana}

Korkea osaamisen taso on tärkeä selitys Pohjoismaiden kansainväliseen asemaan. Maksuton koulutus tarjoaa yksilölle kehitysmahdollisuuksia, mikä hyödyttää elinkeinoelämän kilpailukykyä. Tutkijoilla ja muilla osaamissektorilla työskentelevillä on suuret kehitysmahdollisuudet omilla erikoisaloillaan, koska he voivat työskennellä kaikissa Pohjoismaissa oman maansa lisäksi. Pohjoismaiden tutkimus on useilla aloilla kansainvälisesti tunnustettua, esimerkiksi uuden tekniikan ja infrastruktuurin, terveyden, ympäristön ja ilmaston aloilla arktisen alueen kysymyksiä unohtamatta.

Pohjoismainen tietoyhteiskunta voi sekä auttaa tuomaan peruskoulutusta paremmin useampien saataville maailmassa että olla osa maailman huippuluokan tutkimusta.

Tutkimuksen tason parantamiseksi entisestään olemme riippuvaisia muusta maailmasta. Tuomalla esiin tutkijoiden kehitysmahdollisuuksia pyrimme houkuttelemaan useampia tekemään aluevaltauksia Pohjoismaiden kansainvälisessä tutkimusympäristössä.

\subsubsection{Pohjoismainen luovuus ja innovointi}

Pohjoismaiden kärkisijat luovuuden ja innovointikyvyn kansainvälissä mittauksissa perustuvat pohjimmiltaan pohjoismaiseen malliin.

Koulutus- ja tutkimuspanostusten lisäksi sosiaaliturvajärjestelmä sallii mahdollisuuden ottaa riskejä ja epäonnistua. Elinkeinoelämä on suurelta osin erikoistunutta ja korkeateknologista ja on suuret mahdollisuudet kehittää ja kehittyä osana teollisuutta.

Pyrkimys ympäristön, talouden ja yhteiskunnan kestävään kehitykseen asettaa vaatimuksensa kansainväliselle yhteistyölle. Pohjoismaiden vahvuusalueita ovat etenkin vihreä ja puhdas teknologia (cleantech), biotalous, digitaalinen teknologia, yrittäjyys sekä terveys ja hyvinvointi.

14 Behöver den nordiska modellen förändras? Elinkeinoelämän tutkimuslaitos ETLA \& Pohjoismaiden ministerineuvosto (2014)

15 The Nordic Way, World Economic Forum, Svenska Institutet (2012). 
Kulttuurin asema koko kansan keskuudessa ja sen läheinen yhteys pohjoismaisiin arvoihin on osaltaan edesauttanut luovien alojen kuten kirjallisuuden, elokuvan, musiikin, muotoilun, arkkitehtuurin, ruokakulttuurin ja tietokonepelien kehitystä. Yhdestä näkökulmasta kulttuuri on kasvun väline, kuten alan vuosia jatkunut pohjoismainen menestys osoittaa.

Toimimalla usealla rintamalla - profiloimalla, pyrkimällä yhteistyöhön ja tekemällä kauppoja - edistämme osaltamme innovatiivisia ja luovia ratkaisuja, jotka perustuvat kestävään ajatteluun.

\subsubsection{Pohjoismaiden kulttuuri ja luonto}

Katsomme maailmaa pohjoisesta näkökulmasta, mikä antaa meille perspektiivimme. Suurelta osin yhteinen kulttuurimme on pohjoismaisen yhteistyön ja Pohjola-käsitteen perusta.

Avoimuutta, kansan osallistumista ja vallan läheisyyttä koskevat arvot ovat pohjoismaisen mallin peruskiviä. Ne tekevät pohjoismaisesta kulttuuri-ilmaisusta omanlaistaan, mikä kiinnostaa entistä enemmän muuta maailmaa ja näkyy käsitteinä Nordic Noir, Nordic Design, New Nordic Food ja Nordic Music Wonder.

Pohjoismaalaisten historiallisesti vahva side luontoon ja sen luoma suhde ympäristöön on olennainen osa kulttuuria, mutta myös varsinaista luontosuhdetta. Kulttuurin, luonnon ja yhteiskuntavastuun vuorovaikutuksessa pyrimme hallinnoimaan perintöämme hyvin. Yhteinen vastuu luonnonvaroista sekä inhimillisistä voimavaroista luonnehtii päätöksentekoa sekä elinkeinoelämässä että politiikassa.

Pohjoismaissa on hyvin tilaa. On lakeuksia, korkeita vuoria, suuria metsiä, aavoja meriä, joita ihmiset voivat vapaasti hyödyntää, sillä työmarkkinamallimme antaa työn lisäksi mahdollisuuden myös vapaa-aikaan. Ihmisen huomioiva kestävä ajattelu vaikuttaa politiikkaan yleisesti.

Kulttuuri ja luonto ovat keskeisiä Pohjoismaiden profiloinnissa. Ne ilmentävät alueella asuvien historiaa ja tänne muuttaneet kutsutaan osalliseksi kaikesta tästä, mikä vaalii paikkaamme maailmassa. Tarjoamme täyslaidallisen kulttuuri- ja luontoelämyksiä tänne tuleville matkailijoille ja toivomme, että he palaavat kotiin ja toimivat meidän ja arvojemme lähettiläinä. 


\subsubsection{Muut toimet}

On syytä huomioida, että suurehkot panostukset eivät sulje pois muita toimia maissa, eri aloilla tai pohjoismaisen yhteistyön piirissä. Kuten sanottu, strategia ei pyri rajoittamaan maiden tai toimijoiden omaa profilointityötä. Yhteispohjoismaisen profilointi- ja asemointistrategian tavoitteena on täydentää ja vahvistaa jokaisen maan omaa tavaramerkkiä tarjoamalla mahdollisuus selkeämpään ja johdonmukaisempaan yhteisen alueen kuvaan.

\subsection{Priorisoidut maantieteelliset alueet}

Profilointitoimien on keskityttävä alueille, joilla Pohjoismailla on selviä maailmanlaajuisia kilpailuetuja ja joilla saavutetaan lisäarvoa esiintymällä pohjoismaisesti. Sektoreiden toimijat koordinoivat maantieteellisten alueiden valintaa kuhunkin alueeseen kohdistuvaan kiinnostukseen pohjautuen.

Seuraavat maantieteelliset panostusalueet on valittu ympäröivän maailman, maiden ja pohjoismaisten yhteistyöelinten laajan kytkentäprosessin pohjalta.

\subsubsection{Pohjoismaiden alueelliset naapurit}

Vakiintuneesta yhteistyöstä kannattaa pitää hyvää huolta. Pohjoismaat ovat tehneet vuosia alueellista yhteistyötä etenkin Itämeren alueella ja muiden EU-jäsenmaiden kanssa. Monilla pohjoismaisilla toimijoilla on tiiviitä suhteita näillä alueilla ja Pohjoismaiden vahvuudet kiinnostavat yhä enemmän.

\subsubsection{Kaukomarkkinat}

Mitä kauemmaksi Pohjoismaista mennään, sitä vähemmän siellä tiedetään yksittäisistä maista. Kaukomarkkinoilla on järkevämpää keskittyä Pohjolaan yhtenä käsitteenä ja yhteispohjoismaisilla aloitteilla saavutetaan suurempi hyöty.

Tämä koskee erityisesti BRIC-maita (Brasilia, Venäjä, Intia ja Kiina) sekä Etelä-Afrikkaa, joilla on yhä enemmän vaikutusvaltaa maailmanlaajuiseen kehitykseen sekä merkitystä Pohjoismaiden pitkän aikavälin panostusten kannalta. Yhdysvaltoihin ja Kanadaan on jo hyvät suhteet, joita kannattaa tiivistää. 


\section{Kohderyhmät}

Maiden ja alueiden profilointiin ja asemointiin osallistuu monia osapuolia ja sen vuoksi työllä on yleisen tason laajoja kohderyhmiä. Tämän vuoksi strategiassa ei mainita yksittäisiä kohderyhmiä. Jokainen toimi on ainutlaatuinen ja sen tulee määritellä kohderyhmänsä tarkkaan. Tieto kohderyhmien konkreettisista tarpeista on edellytys, jotta Pohjoismaat koettaisiin kiinnostavina ja relevantteina. Tämän vuoksi ennen jokaista profilointihanketta tehdään perusteellinen analyysi oleellisten kohderyhmien tunnistamiseksi. ${ }^{16}$ 


\section{Tavoitteet}

Koska tämä strategia suuntautuu laajalle pohjoismaisten toimijoiden joukolle, joilla on tavoitteita eri alueilla, yleiset tavoitteet kuvaillaan ilman konkreettisia vaikutustavoitteita. Jokaisessa kansainvälisessä profilointialoitteessa on kuitenkin määriteltävä tarkat vaikutustavoitteet sekä seurattava ja arvioitava niiden toteutumista. Pohjoismaiden ministerineuvoston sihteeristöllä on vastuu tulosten kokonaisarvioinnista ja analysoinnista tavoitteena kehittää osaamista kansainvälisten profilointitoimien toteuttamiseksi.

Strategian tarkoitus ja pitkän aikavälin tavoite on, että Pohjolan ja Pohjoismaiden kilpailukyky ja kansainvälinen vaikuttavuus vahvistuvat yhteisenä aloitteena toteutettavilla koordinoiduilla profilointitoimilla. Tämä saavutetaan seuraavasti:

- Pohjoismaiden ministerineuvosto ottaa vastuun aloitteiden koordinoimisesta ja systematisoimisesta tämän asiakirjan strategisten linjausten mukaisesti.

- Pohjoismaiden ministerineuvoston sihteeristö kehittää tämän strategian mukaisen viestintäalustan sekä käytännön välineitä, jotka inspiroivat, edistävät ja tukevat profilointityötä kaikkien sidosryhmien kannalta.

- Pohjoismaiden ministerineuvosto varaa tarkoitukseen keskitetysti hallinnoitavan budjetin, joka mahdollistaa näkyvimpien ja tehokkaampien profilointitoimien kehittämisen.

- Pohjoismaisen yhteistyön ja Pohjoismaiden toimijat tekevät strategian pohjalta aloitteita.

Tämän seurauksena saavutetaan:

- Pohjoismaiden parempi näkyvyys, enemmän tietoa Pohjoismaista ja suurempi kiinnostus Pohjoismaita kohtaan ensisijaisten kohderyhmien keskuudessa ja priorisoiduilla maantieteellisillä alueilla

- toteutettavien yhteistoimien parempi vaikuttavuus

- todistettu kustannustehokkuus ja koordinointivaikutus toteutettujen toimien osalta.

Strategian voimassaolokauden jälkeen vaikutukset arvioidaan yleisesti jokaisen yksittäisen hankkeen saavuttamien vaikutustavoitteiden perusteella. Tulokset ovat suuntaa-antavia strategian päivityksen yhteydessä vuonna 2018 päätettävien konkreettisten tavoitteiden osalta. 


\section{Hankkeiden ja toimien menestyksen kriteerit}

\section{Ympäristöanalyysi ajoituksen ja kohderyhmän osalta}

Hyöty on suurin, kun tiedetään, että tietyn paikan valittu yhteistyökumppani on kiinnostunut yhteisestä hyödystä ja tarvitsee sitä. Tunnistamalla ja ymmärtämällä ympäröivän maailman tarpeet on mahdollista tehdä oikeita priorisointeja.

\section{Paikallisten yhteistyökumppaneiden käyttö}

Profilointi toteutetaan mieluiten yhteistyössä paikallisen yhteistyökumppanin kanssa, joka auttaa viestin välittämisessä. Kokemus on osoittanut, että uskottavuus ja vaikuttavuus kasvaa, kun profilointiin osallistuu myös toinen osapuoli. Esimerkki tästä on Kennedy Center, jonka rooli Nordic Cool -kulttuurifestivaalin onnistumisessa vuonna 2013 oli täysin ratkaiseva.

\section{Laajempaa ja rajoja koettelevaa ajattelua}

Kaikki maat ja alueet ovat aktiivisia monilla areenoilla ja monien kanavien kautta. Tietovirta on valtavaa. Koordinoitu ja arvoa luova toiminta loppuun mietittyjen viestien kanssa vaatii enemmän työtä, mutta antaa kuitenkin enemmän vaikutusta ja lisää synergiaa.

\section{Pitkäjänteisyys, suunnittelu ja osallistaminen}

Yksittäiset ja satunnaiset panostukset eivät johda mihinkään, vaan ovat lähinnä rahan haaskausta. Useiden eri koordinoitujen aloitteiden pitkän aikavälin suunnittelu tuo tuloksia. Profiloinnin voi ajatella mukaan yhtenä mahdollisuutena kaikessa toiminnan suunnittelussa ja yhteistyö on hyvä käynnistää ajoissa. Toiminnan onnistunut koordinointi toimijoiden kesken on ratkaisevaa.

\section{Arviointi ja sinnikkyys}

Mittaukset ja arvioinnit nostavat osaamisen tasoa ja lisäävät mahdollisuuksia parannuksiin. Kokemustenvaihto pohjoismaisella tasolla luo enemmän osaamista kuin kansallisella tasolla. Vahvistamalla toiminnan tuloksena syntyneitä suhteita luodaan kauaskantoisia ja hyödyllisiä yhteyksiä. 


\section{Budjetti}

Vuodesta 2016 lähtien perustetaan keskitetty budjettikohta koordinointityölle tavoitteena tunnistaa, valmistella ja koordinoida suuria kansainvälisiä profilointipanostuksia, minkä jälkeen asianosaiset julkisen ja yksityisen sektorin toimijat tekevät tuovat osuutensa niiden toteuttamiseksi.

Pohjoismaiden ministerineuvoston sihteeristöllä on vastuu ylläpitää profilointityön ammattitaitoa sekä koordinoida ja laatia yhteisiä viestintätuotteita ja käytännön välineitä. Aikomuksena on perustaa neuvoa-antava ryhmä, jonka tehtävänä on taata valittujen toimien laatu ja niiden toteutus profilointistrategian mukaisesti. Ryhmän jäsenet ovat asiantuntevia edustajia jokaisesta Pohjoismaasta. 


\section{Aikataulu ja toteutus}

Strategia on voimassa 2015-2018. Siihen liittyvää toimintasuunnitelmaa ja muita käytännön välineitä päivitetään jatkuvasti ja vähintään kerran vuodessa. Pitkäjänteisyys ja jatkuvuus on tärkeää, mutta tarvitaan myös vuosittaista päivitystä uusien mahdollisuuksien huomioimiseksi sekä strategisten priorisointien asteittaista konkretisointia tulosten ja kokemusten perusteella.

Vuosi 2015 on strategian ja sen välineiden toteuttamisvuosi. Ensimmäisessä vaiheessa strategia käännetään muille pohjoismaisille kielille sekä englanniksi. Seuraavaksi strategia lähetetään virallisesti esitutkimukseen ja varsinaisen strategian laatimiseen osallistuneille tahoille.

Tässä vaiheessa käynnistetään työ, jonka tavoitteena on kehittää ja systematisoida välineitä ja aineistoa Pohjoismaiden kansainvälisen profiloinnin ja asemoinnin parissa tehtävän työn tueksi. Toisessa vaiheessa välineet julkaistaan www.norden.org-verkkosivustossa ja otetaan käyttöön verkostossa. Pohjoismaiden ministerineuvoston sihteeristö on vastuussa täytäntöönpanosta pohjoismaisen yhteistyön puitteissa ja avustaa täytäntöönpanoa maissa ja muiden toimijoiden keskuudessa.

\subsection{Täytäntöönpanon aikataulu}

- 27. lokakuuta 2014: Pohjoismaiset yhteistyöministerit hyväksyvät Pohjoismaiden kansainvälisen profilointi- ja asemointistrategian.

- Marras-joulukuu 2014: Ohjelma käännetään pohjoismaisille kielille ja englanniksi.

- Tammikuu 2015: Strategia lähetetään kaikille asianomaisille.

- 2014-2015: Tuotetaan aineisto ja välineet (viestintäalusta, verkkosivusto, julkaisuja, tilastoja, asiakirjamalleja ja muita välineitä).

- Vuoden 2015 puoliväli: Järjestetään työpajoja strategian ja välineiden täytäntöön panemiseksi.

- Suunnitellaan suurehkoja aloitteita vuosiksi 2016-2018 (tässä yhteydessä on muistettava, että Tanska vuoden 2015 puheenjohtajamaana on jo tehnyt tiettyjä priorisointeja). 


\section{Käytännön välineet}

Pohjoismaiden ministerineuvoston sihteeristön tehtävänä on auttaa ja koordinoida yhteisessä strategiatyössä. Sihteeristö auttaa osaltaan aloitteiden laadun varmistamisessa ja sillä on vastuu käytännön välineiden tarjoamisesta ja koordinoinnista. Tarkoituksena on ottaa käyttöön välineitä, jotka inspiroivat, edistävät ja helpottavat profilointityötä kaikkien osapuolten keskuudessa. Välineitä voidaan hyödyntää kokonaisuudessaan tai yhdistää omiin viesteihin ja välineisiin.

\section{Profilointityön tueksi tarjotaan seuraavia välineitä:}

\section{Viestintäalusta}

Viestintäalustan tarkoituksena on tukea profilointistrategian mukaisesti toimijoiden kykyä viestiä ja tuoda Pohjoismaita esiin kansainvälisesti ja varmistaa viestinnän johdonmukaisuus. Alustaan sisältyvät:

- yleinen ja lyhyt Pohjoismaiden vahvuuksien kuvaus strategian mukaisesti

- viestintäprosessin malli

- tarkastuslista tulevien hankealoitteiden arvioimiseksi

- vaikutustavoitteiden suuntaviivat

- kohderyhmien tunnistamisen suuntaviivat

- pohjoismaisen tarinan käyttö.

Yhteisten panostusten toimintasuunnitelma

Profilointi- ja asemointimahdollisuuksia sisältävien aloitteiden ja toiminnan kartoitus sekä muun muassa selvitys pohjoismaisista ministerivaltuuskunnista ja niiden mahdollinen koordinointi tavoitteena koordinoida tehokkaasti profilointia edistäviä matkoja.

\section{Suurehkon profilointihankkeen malli}

Hyvin määritelty rakenne (malli), joka voidaan ottaa heti käyttöön, kun on tehty päätös suuren kansainvälisen profilointihankkeen toteuttamisesta. Tämä rakentuu Tanskan puheenjohtajakauden aikana vuonna 2015 saaduille tuloksille sekä kokemuksille Nordic Cool -kulttuurifestivaalin parissa tehdystä työstä vuonna 2013.

Ajankohtaista tilastotietoa ja maatietoutta Pohjoismaista Laaditaan väline päivitettyjen tietojen ja tilastojen laatimiseen ja esittämiseen. Pohjoismaat sijoittuvat esimerkiksi kansainvälisissä mittauksissa korkealle ja tutkimustulokset on tuotava yleisesti saataville. 
Yleiskatsaus ja päivitettyä tietoa Pohjoismaiden vahvuuksista ja menestystarinoista - Nordic Talking Points

Pohjoismaisten ydinarvojen ja vahvuuksien yleiskatsaus ja lyhyt esittely viestintätyön tueksi strategisten profilointialueiden mukaan luokiteltuna.

Tietopankki toteutetuista toimista saaduista kokemuksista Tavoitteena on jakaa tietoa profilointi- ja asemointityöstä saatavista kokemuksista ja niiden yhteydessä laadittavista analyyseista ja mittauksista. 


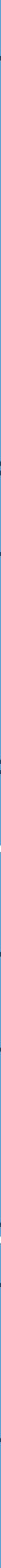




\section{norden}

Pohjoismaiden ministerineuvosto

Ved Stranden 18

DK-1061 København K

www.norden.org

\section{Pohjoismaiden kansainvälinen profilointi- ja asemointistrategia}

Pohjolassa on vetovoimaa. Pohjoismainen ruoka, muotoilu, elokuva, musiikki ja kirjallisuus ovat jo pitkään tehneet Pohjoismaista tunnettuja kansainvälisesti. Menestystarinoita syntyy kaikissa Pohjoismaissa ja usein niihin liittyy pohjoismainen ulottuvuus - pohjoismainen tavaramerkki.

Kansainväliseen tietouteen Pohjola nousi toden teolla kuitenkin vasta talouskriisin jälkimainingeissa. Kriisi osoitti, että pohjoismainen yhteiskunta- ja hyvinvointimalli pystyi taas kerran uudistumaan, mikä antoi muille valtioille aihetta pohtia, voisiko pohjoismainen malli toimia mahdollisena puskurina ja vakiinnuttavana tekijänä yhä epävakaammaksi muuttuvassa maailmantaloudessa. 